\title{
Hubungan Gaya Belajar Dengan Tingkat Prestasi Mahasiswa Fakultas Kedokteran Universitas Islam Sumatera Utara Angkatan Tahun 2013
}

\author{
Siska Anggreni Lubis ${ }^{(1)}$, Mega Dwi Pertiwi ${ }^{(2)}$, Saiful Batubara ${ }^{(3)}$ \\ Dosen PNS DPK Kopertis Fakultas Kedokteran Universitas Islam Sumatera Utara
}

Siskaanggrenilubis@yahoo.com ${ }^{(1)}$, megadwipertiwi@ygmail.com ${ }^{(2)}$, saifulbatubara24@gmail.com ${ }^{(3)}$

\begin{abstract}
ABSTRAK
Strategi belajar yang menarik minat mahasiswa secara tidak langsung akan berpengaruh pada proses belajar . Selama mahasiswa mempunyai inisiatif sendiri dalam belajar, maka ia akan menunjukkan minat yang tinggi untuk belajar sehingga akan menghasilkan ketekunan dan ketertarikan dalam belajar. Hal tersebut juga akan mengarahkan mahasiswa untuk menentukan sendiri tipe belajar yang disukainya. Tujuan penelitian ini untuk mengetahui hubungan gaya belajar mahasiswa dengan tingat prestasi belajar dan pengaruh gaya belajar terhadap tingkat prestasi. Penelitian ini menggunakan jenis penelitian analitik dengan metode cross sectional . Sampel pada penelitian ini berjumlah 87 responden yang diambil dengan metode simpel random sampling. Alat ukur yang dipakai dalam penelitian ini menggunakan kuesioner. Data yang diperoleh kemudian diolah dengan menggunakan kuesioner . data yang diperoleh kemudian diolah dengan menggunakan sistem komputerisasi dan ditampilkan dalam bentuk presentasi. Hasil penelitian yang dilakukan dapat diperoleh bahwa mahasiswa menggunakan gaya belajar visual 21 responden $(50,0 \%)$ mendapatkan IP sangat memuaskan dibandingkan mahasiswa yang menggunakan gaya belajar auditori 17 responden $(70,8 \%)$ mendapatkan IP sangat memuaskan, dan kinestetik 12 responden $(80,0 \%)$ mendapatkan IP sangat memuaskan.hasil uji chi-square yang dilakukan pada penelitianini didapatkan bahwa $\mathrm{p}=$ value $0,0000<$ dari pada $\mathrm{p}=0,05$.
\end{abstract}

Kata kunci : gaya belajar, tingkat prestasi

\begin{abstract}
That ways of learning strategies will attracts students indirectly influence to the learning process. When the students have self initiative in the studying their own showing high interest in learning result will produce diligence and interesting about study. That is make the students to choose themselves preffered types of learning. The purpose of these researche to find out learning styles with levels of learning achievement. The research is analitic research with cross sectional methode. The sample in the research amount 87 , the research was taken by using simple random sampling method. The instrument in this research is questionnaire. The data got from this questionnaire. The data got from questionnaraire were counted by using computer and presented in percentage. The result of this research was obtainablle the students with visual learning styles 21 respondents $(50,0 \%)$ got very satisfying IP be compared with the students with auditory learning styles 17 respondents $(70,8 \%)$ got very satisfying IP, and kinesthetic 12 respondents $(80,0 \%)$ got very satisfying IP . The results chi-square in the research got $\mathrm{p}=$ value $0,000<$ from $\mathrm{p}=0,05$
\end{abstract}

\section{Keyword : learning styles, level of achievement}

\section{PENDAHULUAN}

Belajar adalah proses perubahan perilaku secara aktif yang diarahkan pada suatu tujuan. Suatu proses berbuat melalui berbagai pengalaman, proses melihat, mengamati, dan memahami sesuatu yang dipelajari. Menurut Uno (2006:143\&158) mengidentifikasi berupa bakat, motivasi belajar, gaya belajar, kemampuan berfikir, minat, sikap, kemampuan awal mahasiswa dapat dijadikan sebagai petunjuk dan mendiskripsikan perencanaan pengelolaan pembelajaran. Gaya belajar sebagai salah satu aspek merupakan kombinasi dari bagaimana seseorang menyerap dan kemudian mengatur serta mengolah informasi (Bobbi Deporter: 112). Terdapat 3 (tiga) tipe gaya belajar yaitu Visual 
(cenderung belajar melalui apa yang mereka lihat), Auditory (cenderung belajar melalui apa yang mereka dengar) dan kinestetik (belajar dengan cara bergerak, bekerja dan menyentuh). Hasil belajar seseorang ditentukan oleh berbagai faktor yang digambarkan sebagai tingkat penguasaan mahasiswa terhadap sasaran belajar pada topik bahasan yang diukur berdasarkan pada jumlah skor. Hasil belajar masih tetap menjadi indikator untuk menilai tingkat keberhasilan siswa dalam proses belajar. Hasil belajar yang baik dapat mencerminkan gaya belajar yang baik karena dengan mengetahui dan memahami gaya belajar yang terbaik bagi dirinya akan membantu mahasiswa dalam belajar sehingga prestasi yang dihasilkan akan maksimal. Gaya belajar mempengaruhi ingatan dan pemahaman yang komprehensif. Pada penelitian Lisiswanti (2014) hubungan gaya belajar dan hasil belajar mahasiswa dengan uji koefisien kontingensi diperoleh hasil 0,122 hubungan ini positif sangat lemah. Berbeda dengan penelitian Ogundokun (2011) mendapatkan bahwa gaya belajar, lingkungan dan kecemasan meramalkan hasil belajar seseorang. Hasil penelitian Montemayor et al. (2009) menunjukan tidak ada perbedaan yang signifikan antara gaya belajar mahasiswa dengan nilai lemah dan tinggi. Agar tujuan pembelajaran tercapai dengan baik secara efektif dan efisien, maka gaya belajar mahasiswa perlu diperhatikan dan dipertimbangkan. Dengan mengetahui mengetahui gaya belajar, mahasiswa dapat menerapkan cara belajar yang baik dan sesuai dengan gaya belajarnya, sehingga mahasiswa dapat memaksimalkan prestasi akademik dan non akademik.

\section{BELAJAR}

Belajar atau learning merupakan fokus utama dalam psikologi pendidikan. Suryabrata (1984) dan Masrun dan Martianah (1972) mengemukakan bahwa pada dasarnya belajar merupakan sebuah proses untuk melakukan perubahan prilaku seseorang, baik lahiriah maupun batiniah. Perubahan menuju kebaikan, dari yang jelek menjadi yang baik. Proses perubahan tersebut sifatnya relatif permanen dalam artian bahwa kebaikan yang diperoleh berlangsung lama dan proses perubahan tersebut dilakukan secara adaptif, tidak mengabaikan kondisi lingkungannya. Menurut pengertian secara psikologis, belajar merupakan suatu proses perubahan yaitu perubahan tingkah laku sebagai hasil dari interaksi dengan lingkungannya dalam memenuhi kebutuhan hidupnya. Perubahanperubahan tersebut akan nyata dalam seluruh aspek tingkah laku secara keseluruhan, sebagai hasil pengalamannya sendiri dalam interaksi dengan lingkungannya

Faktor - Faktor yang mempengaruhi belajar

a. Faktor - Faktor Internal, (faktor dari dalam diri) yaitu:

- Faktor jasmaniah (kesehatandan cacat tubuh)

- Faktor psikologis (intelegensia,perhatian, bakat, minat, motivasi, kematangan dan kesiapan

- Faktor kelelahan (jasmani dan rohani)

b. Faktor eksternal (Faktor dari luar diri) terdiri dari :

- Faktor keluarga (cara orang tua mendidik, relasi antar anggota keluarga, keadaan ekonomi, pengertian orang tua, latar belakang kebudayaan)

- Faktor sekolah yang mempengaruhi belajar mencakup metode mengajar, kurikulum, relasi guru dengan siswa, relasi siswa dengan siswa, disiplin sekolah, pelajaran dan waktu sekolah, standar pelajaran, keadaan gedung, metode belajar dan tugas rumah

- Faktor masyarakat anatar lain keberadaan siswa dalam masyarakat seperti kegiatan siswa dalam masyarakat, media massa, teman bergaul dan bentuk kehidupan masyarakat, yang semuanya mempengaruhi belajar siswa 
Siska Anggreni Lubis, Mega Dwi Pertiwi, Saiful B : Hubungan Gaya Belajar Dengan Tingkat Prestasi Mahasiswa Fakultas Kedokteran Universitas Islam Sumatera Utara Angkatan Tahun 2013

\section{GAYA BELAJAR}

Pendekatan belajar berpengaruh terhadap tingkat keberhasilan proses pembelajaran seseorang. Selain pendekatan, gaya belajar termasuk faktor struktural Jonassen dan Grabowski (1993) berpendapat bahwa satu perkembangan minat pada gaya kognitif merupakan bagian dari evolusi dari gaya belajar, yang secara umum cenderung lebih suka untuk memproses informasi pada situasi dan cara yang berbeda. Gaya belajar merupakan sebuah pendekatan yang menjelaskan mengenai bagaimana individu belajar atau cara yang ditempuh oleh masing-masing orang untuk berkonsentrasi pada proses, dan menguasai informasi yang sulit dan baru melalui persepsi yang berbeda. Tiga modalitas pembelajaran ini pertama kali dikembangkan oleh Neil Fleming (2001) untuk menunjukan preferensi individu dalam proses belajarnya, yakni Visual, Auditory, Kinestetik. Meskipun ketiga modalitas tersebut hampir semuanya dimiliki oleh setiap orang, tetapi hampir semua dari mereka selalu cenderung pada salah satu diantara ketiganya. Ketiga modalitas ini digunakan untuk pembelajaran, dan komunikasi. Bahkan, beberapa orang tidak hanya cenderung pada satu modalitas saja, mereka bisa memanfaatkan kombinasi modalitas tertentuk untuk meningkatkan kemampuan belajar. Rita Dunn, seorang pelopor dibidang gaya belajar, telah menemukan banyak variabel yang mempengaruhi cara belajar orang. Ini mencakup faktor-faktor fisik, emosional, sosiologi, dan lingkungan.

\section{a. Tipe Gaya Belajar}

Mengetahui karakteristik pelajar visual, auditorial, dan kinestetik akan membantu anda mencurahkan diri pada modalitas belajar yang baik. Terdapat ciri-ciri tipe gaya belajar yang dimiliki setiap orang ${ }^{1}$

\section{Visual}

Gaya belajar visual tergambar pada seseorang siswa yang biasa duduk tegak dan melihat lurus kedepan ketika belajar atau matanya memandang ke atas ketika menerima informasi dan ketika berbicara, ia selalu cepat. Jelasnya, gaya belajar visual adalah belajar dengan cara melihat. Adapun ciri-ciri orang yang belajar dengan tipe visual ialah ${ }^{4}$ :

a. Rapi dan teratur

b. Berbicara dengan cepat

c. Perencanaan dan pengatur jangka panjang yang baik

d. Teliti terhadap detail

e. Mementingkan penampilan, baik dalam hal pakaian maupun prestasi

f. Pengeja yang baik dan dapat melihat kata-kata yang sebenarnya dalam pikiran mereka

g. Mengingatkan apa yang dilihat, dari pada yang didengar

$\mathrm{h}$. Mengingatkan dengan asosiasi visual

i. Biasanya tidak terganggu oleh keributan

j. Mempunyai masalah untuk mengingat instruksi verbal kecuali jika ditulis, dan sering kali minta bantuan orang untuk menggulanginya

k. Pembaca cepat dan tekun

1. Lebih suka membaca dari pada dibacakan

m. Membutuhkan pandangan dan tujuan yang menyeluruh dan bersikap waspada sebelum secara mental merasa pasti tentang suatu masalah atau proyek

n. Mencoret-coret tanpa arti selama berbicara ditelepon dan dalam rapat

o. Lupa menyampaikan pesan verbal kepada orang lain

p. Sering menjawab pertayaan dengan jawaban singkat ya atau tidak 
Siska Anggreni Lubis, Mega Dwi Pertiwi, Saiful B : Hubungan Gaya Belajar Dengan Tingkat Prestasi Mahasiswa Fakultas Kedokteran Universitas Islam Sumatera Utara Angkatan Tahun 2013

q. Lebih suka melakukan demonstrasi dari pada berpidato

r. Lebih suka seni dari pada musik

s. Sering kali mengetahui apa yang harus dikatakan, tetapi tidak pandai memilih kata - kata

t. Kadang-kadang kehilangan konsentrasi ketika mereka ingin memperhatikan

\section{Auditory}

Tipe auditory belajar melalui apa yang mereka dengar. Ketika anda tidak dapat membuat dari ilustrasi yang diberikan tetapi saat menelpon tokonya dan seseorang dapat menjelaskan kepada anda bagaimana merangkainya, dan semuanya menjadi lebih jelas. Adapun ciri-ciri tipe belajar auditory ialah : ${ }^{1}$

a. Berbicara kepada diri sendiri

b. Mudah terganggu oleh keributan

c. Menggerakkan bibir mereka dan mengucapkan tulisan dibuku ketika membaca

d. Senang membaca dengan keras dan mendengarkan

e. Dapat mengulangi kembali dan menirukan nada, berirama, dan warna suara

f. Merasa kesulitan dalam menulis tetapi pandai dalam bercerita

g. Berbicara dalam irama yang berpola

h. Biasanya pembicara yang fasih

i. Lebih suka musik daripada seni

j. Belajar dengan mendengarkan dan mengingat apa yang didiskusikan dari pada yang dilihat

k. Suka berbicara, suka berdiskusi, dan menjelaskan sesuatu panjang lebar

1. Mempunyai masalah dengan pekerjaan-pekerjaan yang melibatkan visualisasi, seperti memotong bagian-bagian hingga sesuai satu sama lain

$\mathrm{m}$. Lebih pandai mengeja dengan keras dari pada menuliskannya

n. Lebih suka gurauan lisan dari pada membaca komik

3. Kinestetik

Gaya belajar kinestetik tergambar pada seorang siswa kidal yang sering bergerak, memandang kekanan dan kebawah ketika menerima dan menyimpan informasi, serta lambat dalam berbicara. Jelasnya, gaya belajar kinestetik adalah belajar dengan cara bergerak, bekerja dan menyentuh. Adapun ciri-ciri tipe belajar kinestetik ialah : ${ }^{4}$

a. berbicara dengan perlahan

b. menanggapi perhatian fisik

c. Menyentuh orang untuk mendapatkan perhatian mereka

d. Berdiri dekat ketika berbicara dengan orang

e. Selalu berorientasi pada fisik dan banyak gerak

f. Mempunyai perkembangan awal otot-otot yang besar

g. Belajar melalui memanipulasi dan praktik

h. Menghafal dengan cara berjalan dan melihat

i. Menggunakan jari sebagai penunjuk ketka membaca

j. Banyak menggunakan isyarat tubuh

k. Tidak dapat duduk diam dalam waktu yang lama

1. Tidak dapat mengingat geogarafi, kecuali jika mereka memang telah pernah berada ditempat itu

m. Menggunakan kata-kata yang menggandung aksi

n. Menyukai buku-buku yang berorientasi pada plot-mereka mencerminkan aksi dengan gerakan tubuh saat membaca 
o. Kemungkinan tulisannya jelek

p. Ingin melakukan segala sesuatu

q. Menyukai permainan yang menyibukkan

\section{PRESTASI BELAJAR}

Prestasi belajar adalah hasil yang diperoleh siswa atau mahasiswa setelah melakukan aktivitas belajarnya yang dinyatakan dalam bentuk nilai angka atau huruf. Untuk mengetahui seberapa jauh prestasi akademik tersebut, maka diperlukan pengukuran dan penilaian hasil belajar. Pengukuran mencakup segala cara untuk memperoleh informasi mengenai hasil belajar yang dapat dikuantifikasikan. Prestasi belajar lebih jauh dapat diukur tinggi dan rendahnya berdasarkan nilai ujian yang diperoleh, berupa nilai rapor atau IPK (indeks prestasi kumulatif Prestasi belajar merupakan ukuran keberhasilan yang diperoleh siswa selama proses belajarnya. Prestasi belajar akademik merupakan hasil pelajaran yang diperoleh dari kegiatan belajar disekolah atau diperguruan tinggi bersifat kognitif dan biasanya ditentukan melalui pengukuran dan penilaian. Indeks prestasi (IP) adalah penilaian keberhasilan studi semester yang dilakukan pada tiap akhir semester. Penilaian ini meliputi semua mata kuliah yang direncanakan mahasiswa dalam Kartu Rencana Studi (KRS).

\section{Jenis Prestasi Belajar}

Blomm yang secara garis besar membedakan menjadi tiga tingkatan, yaitu :

1. Tingkat Kognitif

Berhubungan dengan hasil belajar intelektual Tingkat Afektif

Berhubungan dengan sikap dan nilai.

2. Tingkat Psikomotorik

Tampak dalam bentuk keterampilan (skill) dan kemampuan bertindak individu. Terdapat enam tingkatan ${ }^{7}$ :

Faktor-Faktor yang Mempengaruhi Proses Belajar dengan Hasil Belajar

Prestasi belajar yang dicapai seseorang merupakan hasil interaksi bebagai faktor yang mempengaruhinya baik dalam diri (faktor internal) maupun dari luar diri (faktor eksternal) individu. Pengenalan terhadap faktor-faktor yan g mempengaruhi prestasi belajar penting sekali artinya dalam rangka membantu mahasiswa dalam mencapai prestasi belajar yang sebaik-baiknya

\section{HUBUNGAN GAYA BELAJAR DENGAN PRESTASI BELAJAR}

Gaya belajar mempunyai peran penting dalam bidang pendidikan. Marton (1986) dengan studi phenomenograhic menemukan sekaligus mengukuhkan suatu kesimpulan tentang hubungan konsep belajar individu sebagai satu usaha yang dilakukan individu untuk belajar, dan hasil usaha individu untuk belajar. Keberadaan dari hubungan tersebut secara spesifik berupa gaya belajar dan pengukuran hasil belajar dan prestasi akademis. Keunikan pada individu perlu diperhatikan bukan sebagai gangguan tetapi sebagai perbedaan, dengan perspektif ini, maka individu yang unik dapat dipandang sebagai pribadi yang utuh. Pribadi yang utuh dengan keunikan akan melakukan proses belajar dengan gaya belajar yang unik pula. Gaya-gaya belajar yang unik ini dapat dipandang sebagai kekayaan yang harus didasari oleh individu itu sendiri dan khususnya bagi mereka yang menjadi orang-orang yang tampil membantu (guru atau pun orang tua) pada proses pembelajaran. 
Siska Anggreni Lubis, Mega Dwi Pertiwi, Saiful B : Hubungan Gaya Belajar Dengan Tingkat Prestasi Mahasiswa Fakultas Kedokteran Universitas Islam Sumatera Utara Angkatan Tahun 2013

\section{METODE PENELITIAN}

Penelitian yang digunakan dalam penelitian ini adalah penelitian Analitik secara Cross Sectional. Penelitian ini dilakukan di Fakultas Kedokteran Universitas Islam Sumatera Utara J1. Karya Bakti dan di Sisingamangaraja 2A. Penelitian ini akan dilakukan pada bulan Januari - Februari 2016. Populasi dalam penelitian ini adalah seluruh mahasiswa/i program Kedokteran Universitas Islam Sumatera Utara yang masih aktif kuliah stambuk dengan jumlah 676. Setelah melalui metode simple random sampling didapatkan sampe sebesar 87 orang. Penentuan besarnya sampel dalam penelitian ini dihitung dengan menggunakan rumus Slovin yaitu:

$$
n=\frac{\mathrm{N}}{\mathrm{Nd}^{2}+1}
$$

Dimana :

$\mathrm{n}=$ Jumlah Sampel

$\mathrm{N}=$ Jumlah Populasi

$d^{2}=$ Presisi (ditetapkan 10\% dengan tingkat kepercayaan 90\%)

Maka berdasarkan rumus tersebut, maka diperoleh jumlah sampel sebagai berikut :

$n=\frac{\mathrm{N}}{N d^{2}+1}=\frac{676}{(676) \cdot(0,1)^{2}+1}=\frac{676}{8,31}=87=87$ responden

Jadi, pengambilan sampel :

Karya bakti $=(327 / 676) \times 87=42$

$2 \mathrm{~A} \quad=(349 / 676) \times 87=45$

\section{HASIL PENELITIAN}

Proses pengambilan data untuk penelitian ini telah dilakukan dengan mengisi lembar kuisoner yang diberikan oleh peneliti kepada responden. Kemudian peneliti melakukan wawancara dengan pertanyaan kepada responden. Hasil dari data yang telah dikumpulkan kemudian dianalisis.Terdapat berbagai gaya belajar yang dimiliki oleh mahasiswa Fakultas Kedokteran Universitas Islam Sumatera Utara tahun 2013, yang sesuai dengan kebiasaan mereka masing-masing dalam proses belajar. Banyak mahasiswa Fakultas Kedokteran Universitas Islam Sumatera Utara tahun 2013 yang menggunakan gaya belajar visual dibandingkan dengan gaya belajar auditori dan kinestetik. Responden yang menjadi sampel dalam penelitian ini adalah mahasiswa Fakultas Kedokteran Universitas Islam Sumatera Utara angkatan 2013 yang terpilih secara acak dengan total responden 87 orang. Karakteristik responden yang diamati melalui tipe belajar, indeks prestasi, jenis kelamin dan kampus. Data dapat dilihat selengkapnya pada tabel berikut.

Tabel 4.1 Distribusi Frekuensi Karakteristik Responden

\begin{tabular}{|c|c|c|}
\hline Karakteristik & Frekuensi & Presentase (\%) \\
\hline Kampus & & 48,3 \\
\hline Karya Bakti & 42 & 51,7 \\
\hline 2A & 45 & 66,7 \\
\hline Jenis Kelamin & 58 & 33,3 \\
\hline Perempuan & 29 & \\
\hline Laki-laki & & 6,9 \\
\hline Gaya Belajar & 6 & \\
\hline $\begin{array}{l}\text { Tidak Mempunyai Gaya } \\
\text { Belajar Yang Dominan }\end{array}$ & & \\
\hline
\end{tabular}


Siska Anggreni Lubis, Mega Dwi Pertiwi, Saiful B : Hubungan Gaya Belajar Dengan Tingkat Prestasi Mahasiswa Fakultas Kedokteran Universitas Islam Sumatera Utara Angkatan Tahun 2013

\begin{tabular}{|c|c|c|}
\hline Visual & 42 & 48,3 \\
\hline Auditori & 24 & 27,6 \\
\hline Kinestetik & 15 & 17,2 \\
\hline Indeks Prestasi & & \\
\hline Cumlaude & 18 & 20,7 \\
\hline Sangat Memuaskan & 50 & 57,5 \\
\hline Memuaskan & 14 & 16,1 \\
\hline Kurang Memuaskan & 5 & 5,7 \\
\hline Total & 87 & 100 \\
\hline
\end{tabular}

Dari tabel 4.1 distribusi frekuensi karakteristik responden berdasarkan kampus dapat diketahui bahwa dari sampel yang diteliti di kampus karya bakti sebanyak 42 responden (48,3\%) dan di kampus 2A sebanyak 45 responden (51,7\%). Distribusi frekuensi responden berdasarkan jenis kelamin dapat dilihat bahwa, responden yang berjenis kelamin perempuan sebanyak 58 orang $(66,7 \%)$ dan yang berjenis kelamin laki-laki sebanyak 29 orang $(33,3 \%)$. Distribusi frekuensi responden berdasarkan gaya belajar dapat dilihat bahwa mahasiswa yang tidak mempunyai gaya belajar yang dominan sebanyak 6 orang $(6,9 \%)$, dimana terdapat skor yang sama atau kurang dari skor minimal atau tidak terdapat skor yang dominan maka responden dikatakan bahwa responden tidak mempunyai gaya belajar yang dominan. Mahasiswa yang memiliki gaya belajar visual sebanyak 42 orang (48,3\%), yang memiliki gaya belajar Auditori 24 orang (24\%) dan mahasiswa yang memiliki gaya belajar kinestetik sebanyak 15 orang $(17,2 \%)$. Distribusi frekuensi responden berdasarkan indeks prestasi dapat dilihat bahwa mahasiswa yang mendapatkan IP cumlaude sebanyak 18 orang (20,7\%), mahasiswa yang mendapat IP sangat memuaskan sebanyak 50 orang $(57,5 \%)$, mahasiswa yang mendapat IP memuaskan sebanyak 14 orang $(16,1 \%)$ dan mahasiswa yang mendapatkan IP kurang memuaskan sebanyak 5 oarang $(5,7 \%)$.

\section{Analisis Bivariat}

Pada penelitian ini analisis bivariat yang digunakan ialah menggunakan uji Chi-Square Tests dengan $\mathrm{p}<0,05$. Adapun variabel independen dalam penelitian ini ialah gaya belajar dengan variabel dependen yaitu tingkat prestasi. hasil analisis data yang telah dibuat sebagai berikut :

\begin{tabular}{|c|c|c|c|c|c|c|c|c|c|c|c|}
\hline \multirow[t]{3}{*}{ Gaya Belajar } & \multicolumn{8}{|c|}{ IP } & & & \\
\hline & \multicolumn{2}{|c|}{$\mathrm{C}$} & \multicolumn{2}{|c|}{ SM } & \multicolumn{2}{|c|}{$\mathrm{M}$} & \multicolumn{2}{|c|}{ KM } & \multicolumn{2}{|c|}{ Total } & P Value \\
\hline & $\mathrm{N}$ & $\%$ & $\mathrm{~N}$ & $\%$ & $\mathrm{~N}$ & $\%$ & $\mathrm{n}$ & $\%$ & $\mathrm{~N}$ & $\%$ & $\mathrm{P}$ \\
\hline Visual & 12 & 28,6 & 21 & 50,0 & 9 & 21,4 & & & 42 & 100 & $P=$ \\
\hline Auditory & 6 & 25,0 & 17 & 70,8 & 1 & 4,2 & & & 24 & 100 & \\
\hline Kinestetik & & & 12 & 80,0 & 3 & 20.0 & & & 15 & 100 & 0,000 \\
\hline \begin{tabular}{lr} 
Tidak & \multicolumn{2}{r}{ Mempunyai } \\
Gaya Belajar & Yang \\
Dominan &
\end{tabular} & & & & & 1 & 16,7 & 5 & 83,3 & 6 & 100 & 0,0 \\
\hline
\end{tabular}

Keterangan $: \mathrm{C}=$ Cumlaude, $\mathrm{SM}=$ Sangat Memuaskan, $\mathrm{M}=$ Memuaskan, $\mathrm{KM}=$ Kurang Memuaskan 
Dari tabel 4.2 Dapat diketahui bahwa mahasiswa yang memiliki gaya belajar visual mayoritas 21 responden $(50,0 \%)$ mendapatkan IP sangat memuaskan, 12 responden $(28,6 \%)$ mendapatkan IP cumlaude, dan 9 responden $(21,4 \%)$ mendapatkan IP memuaskan. Mahasiswa yang menggunakan gaya belajar auditori mayoritas 17 responden $(70,8 \%)$ mendapatkan IP sangat memuaskan, 6 responden $(25,0 \%)$ mendapatkan IP cumlaude, dan 1 responden (4,2\%) mendapatkan IP memuaskan. Mahasiswa yang menggunakan gaya belajar kinestetik mayoritas 12 responden $(80,0 \%)$ mendapatkan IP sangat memuaskan, dan 3 responden $(20,0 \%)$ mendapatkan IP memuaskan. Sedangkan mahasiswa yang tidak mempunyai gaya belajar yang dominan sebanyak 5 responden $(83,3 \%)$ mendapatkan IP kurang memuaskan dan hanya 1 responden $(16,7 \%)$ yang mendapatkan IP memuaskan. Dimana terdapat skor yang sama atau kurang dari skor minimal atau tidak terdapat skor yang dominan maka responden dikatakan bahwa responden tidak mempunyai gaya belajar yang dominan.

\begin{tabular}{|c|c|c|c|c|c|c|c|c|c|c|}
\hline \multirow[t]{3}{*}{ Gaya Belajar } & \multicolumn{10}{|c|}{ IP } \\
\hline & \multicolumn{2}{|c|}{$\mathrm{C}$} & \multicolumn{2}{|c|}{ SM } & \multicolumn{2}{|c|}{$\mathrm{M}$} & \multicolumn{2}{|c|}{ KM } & \multicolumn{2}{|r|}{ Total } \\
\hline & $\mathrm{N}$ & $\%$ & $\mathrm{~N}$ & $\%$ & $\mathrm{~N}$ & $\%$ & $\mathrm{n}$ & $\%$ & $\mathrm{~N}$ & $\%$ \\
\hline $\begin{array}{l}\text { Memiliki Gaya } \\
\text { Belajar }\end{array}$ & 18 & 22,2 & 50 & 61,7 & 13 & 16,0 & & & 81 & 100 \\
\hline $\begin{array}{l}\text { Tidak Memiliki } \\
\text { Gaya Belajar Yang } \\
\text { Dominan }\end{array}$ & & & & & 1 & 16,7 & 5 & 83,3 & 6 & 100 \\
\hline
\end{tabular}

Keterangan : $\mathrm{C}=$ Cumlaude, $\mathrm{SM}=$ Sangat Memuaskan, $\mathrm{M}=$ Memuaskan, $\mathrm{KM}=$ Kurang Memuaskan.

Dari tabel 4.3 dapat diketahui bahwa mahasiswa yang memiliki gaya belajar mendapatkan IP lebih tinggi dengan 18 responden $(22,2 \%)$ mendapatkan IP cumlaude, 50 responden $(61,7 \%)$ mendapatkan IP sangat memuaskan, 13 responden $(16,0 \%)$ mendapatkan IP memuaskan. Sedangkan mahasiswa yang tidak mempunyai gaya belajar yang dominan 5 responden $(83,3 \%)$ mendapatkan IP kurang memuaskan dan 1 responden $(16,7 \%)$ mendapatkan IP memuaskan. dimana terdapat skor yang sama atau kurang dari skor minimal atau tidak terdapat skor yang dominan maka responden dikatakan bahwa responden tidak mempunyai gaya belajar yang dominan

\section{PEMBAHASAN}

\section{Hubungan Gaya Belajar Dengan Tingkat Prestasi}

Banyak mahasiswa yang menggunakan gaya belajar untuk memahami dalam proses belajar baik dirumah maupun saat perkuliahan, mereka menggunakan gaya belajar yang sesuai dengan diri mereka masing-masing. Tetapi ada juga beberapa yang masih belum memiliki atau belum menemukan gaya belajar yang sesuai dengan diri mereka. Gaya belajar sangat diperlukan dalam proses pembelajaran guna untuk mengefektivitaskan proses belajar, maka dari itu mereka perlu memiliki gaya belajar yang sesuai. Hasil penelitian yang dilakukan dapat diperoleh bahwa mahasiswa mengunakan gaya belajar visual 21 responden $(50,0 \%)$ mendapatkan IP sangat memuaskan dibandingkan mahasiwa yang mengunakan gaya belajar auditori 17 responden $(70,8 \%)$ mendapatkan IP sangat memuaskan, dan kinestetik 12 responden $(80,0 \%)$ mendapatkan IP sangat memuaskan. Prestasi belajar yang baik mencermikan gaya belajar yang baik juga, karena ketika mahasiswa mengenali gaya belajar yang diminati maka proses belajar akan berlangsung efektif. Di Fakultas Kedokteran Universitas Islam Sumatera Utara Tahun 2013 yang menggunakan gaya 
Siska Anggreni Lubis, Mega Dwi Pertiwi, Saiful B : Hubungan Gaya Belajar Dengan Tingkat Prestasi Mahasiswa Fakultas Kedokteran Universitas Islam Sumatera Utara Angkatan Tahun 2013

belajar visual lebih banyak dibandingkan dengan auditori dan kinestetik dikarena mereka lebih banyak membaca, karena dalam proses pembelajaran di Fakultas Kedokteran membaca buku dengan berbagai reverensi lebih memaksimalkan ilmu yang mereka dapat dan dapat dikembangkan karena ilmu kedokteran tidak hanya terpaku dalam satu buku. Ilmu kedokteran pun terus berkembang jadi mereka perlu mempunyai strategi dalam proses pembelajaran agar tidak tertinggal dengan perkembangan ilmu. Sejalan dengan penelitian yang dilakukan oleh sundari (2009) data yang diperoleh menunjukkan bahwa mahasiswa dengan tipe belajar visual memiliki prestasi sangat memuaskan 32,7\%, dan memuaskan 18,1\%. Mahasiswa dengan tipe belajar auditori memiliki prestasi sangat memuaskan 16,3\% dan memuaskan 12,7\%. Mahasiswa dengan tipe belajar kinestetik memiliki prestasi sangat memuaskan 3,6\% dan memuaskan 16,4\%. Penelitian yang dilakukan oleh Arlia Septiana (2012) bahwa sebagian besar responden memiliki gaya belajar visual 44,4\% (40 orang) dan sebagian besar memiliki prestasi belajar sangat memuaskan sebesar 48,9\% (44 orang). Terdapat juga gaya belajar kombinasi yang merupakan terdapat lebih dari satu gaya belajar pada satu responden sebanyak 13,3\% (12 orang). Berbeda dengan penelitian yang dilakukan oleh Rika Endah Nurhidayah (2009) menunjukkan bahwa mahasiswa dengan gaya belajar Kinestetik memiliki rata-rata hasil belajar sangat baik (A) yaitu dengan hasil 82,6 sedangkan untuk hasil belajar visual dengan hasil baik (B) yaitu 74,2 dan audio dengan hasil baik juga (B) yaitu 72,2. Penelitian yang dilakukan oleh Hardiansyah (2014) bahwa prestasi belajar mahasiswa kedokteran UNDIP tidak dipengaruhi oleh gaya belajar yang terdiri dari visual, auditori, membaca/menulis dan kinestetik. Akan tetapi untuk gaya belajar tertentu yang menggabungkan dua model gaya belajar misalnya visual kinestetik dapat meningkatkan prestasi belajar mahasiswa. Maka hasil uji Chi-Square yang lakukan pada penelitian ini didapatkan bahwa $\mathrm{p}=$ value $0,000<$ dari pada $\mathrm{p}=0,05$ sehingga dapat disebutkan bahwa Ho ditolak dimana terdapat hubungan antara gaya belajar dengan tingkat prestasi mahasiswa Fakultas Kedokteran Universitas Islam Sumatera Utara Tahun 2013. Uji Chi-Square yang dilakukan pada penelitian Sundari (2009) terhadap hasil penelitian diperoleh nilai signifikasi sebesar 0.033 yang memberikan makna bahwa terdapat hubungan yang signifikan antara tipe belajar dengan prestasi belajar mahasiswa sama dengan uji yang dilakukan oleh peneliti. Tetapi berbeda dengan uji yang dilakukan oleh Hardiansyah (2014) menyatakan bahwa Hubungan semua gaya belajar dengan prestasi akademik diperoleh $\mathrm{p}=0,2$, hubungan gaya belajar unimodal dengan prestasi akademik diperoleh $\mathrm{p}=0,3$, dan hubungan gaya belajar multimodal dengan prestasi akademik diperoleh $\mathrm{p}=0.017$. mahasiswa yang menggunakan gaya belajar lebih dari satu memiliki nilai yang signifikan berhubungan dengan prestasi belajar dibandingkan dengan yang hanya memiliki satu gaya belajar.

\section{Pengaruh Gaya Belajar Terhadap Tingkat Prestasi}

Berdasarkan hasil uji Chi-Square, dapat dinilai bahwa $\mathrm{p}$ value $=0,000$ yang berarti terdapat pengaruh yang signifikan atau bermakna. Maka Ho ditolak atau terdapat pengaruh gaya belajar terhadap tingkat prestasi mahasiswa Fakultas Kedokteran Universitas Islam Sumatera Utara tahun 2013. Hasil penelitian yang telah dilakukan menyatakan bahwa mahasiswa/i yang memiliki gaya belajar lebih banyak mendapatkan IP sangat memuaskan 50 responden $(61,7 \%), 18$ responden $(22,2 \%)$ mendapatkan IP cumlaude, dan 13 responden $(16,0 \%)$ mendapatkan IP memuaskan. Sedangkan mahasiswa yang tidak mempunyai gaya belajar yang dominan sebanyak 6 responden, dimana 5 responden $(83,3 \%)$ mendapatkan IP kurang memuaskan atau dibawah rata-rata, sedangkan $1(16,7 \%)$ responden mendapatkan IP memuaskan. Setiap orang memiliki dan mengembangkan gaya belajar tersendri yang dipengaruhi oleh tipe kepribadian, kebiasaan, serta perkembangan 
sejalan dengan waktu dan pengalaman. Pola atau gaya belajar tersebut dipengaruhi oleh jurusan atau bidang yang digeluti, yang selanjutnya akan turut memengaruhi keberhasilan seseorang dalam meraih prestasi yang diharapkan. Mahasiswa yang belajar tidak menggunakan metode dan teknik yang baik namun memperoleh hasil yang baik, kemungkinan mahasiswa tersebut tidak menyadari bahwa seandainya ia melakukan belajar dengan cara yang tepat pasti akan memperoleh hasil yang lebih baik lagi.

\section{KESIMPULAN}

Berdasarkan hasil penelitian yang diperoleh mengenai "Hubungan Gaya Belajar Terhadap Tingkat Prestasi Mahasiswa Fakultas Kedokteran Universitas Islam Sumatera Utara Tahun 2013" maka dapat disimpulkan sebagai berikut:

1. Ada hubungan antara gaya belajar dengan tingkat prestasi dikarena kan hasil analisis data $\mathrm{p}$ value $=0,000<$ dari pada $\mathrm{p}=0,05$. Gaya belajar visual lebih banyak yaitu sebanyak 21 mahasiswa $(50,0 \%)$ mendapatkan IP sangat memuaskan, dibanding dengan gaya belajar auditori dan kinestetik.

2. Mahasiswa yang memiliki gaya belajar visual sebanyak 42 mahasiswa (48,3\%), yang memiliki gaya belajar Auditori sebanyak 24 mahasiswa (24\%) dan mahasiswa yang memiliki gaya belajar kinestetik sebanyak 15 mahasiswa $(17,2 \%)$.

3. Ada pengaruh gaya belajar terhadap tingkat prestasi karena hasil analisis data terdapat perbedaan yang sangat signifikan $\mathrm{p}$ value $=0,000<$ dari pada $\mathrm{p}=0,05$, yang memiliki gaya belajar lebih banyak mendapatkan IP sangat memuaskan 81 mahasiswa $(61,7 \%)$ sedangkan yang tidak memiliki gaya belajar yang signifikan mendapatkan IP kurang memuaskan 6 mahasiswa $(83,3 \%)$.

\section{SARAN}

1. Bagi Mahasiswa

Sebaiknya mahasiswa menggunakan gaya belajar yang sesuai dalam dirinya, sehingga mahasiswa dapat menentukan cara mereka sendiri dalam memproses dan menyerap pelajaran yang diberikan.

2. Bagi Institusi Pendidikan.

Perlu dilakukan identifikasi terhadap gaya belajar mahasiswa sehingga gambaran gaya belajar mahasiswa akan diketahui secara keseluruhan yang disesuaikan dengan metode pembelajaran.

3. Bagi Peneliti Lain

Banyak faktor yang memepengaruhi tingkat prestasi mahasiswa dalam proses pembelajaran, maka peneliti menyarankan kepada peneliti lain untuk meneliti yang berhubungan dengan faktor-faktor yang mempengaruhi tingkat prestasi mahasiswa. Dan meneliti untuk semester berikutnya

\section{DAFTAR PUSTAKA}

Porter, B, D,. Hernacki, M,. 2013. Quantum Learning. Bandung: Kaifa Learning. Hal 109122.

Lisiswanti, R,. 2014. The Relation Ship Learning Style and Student's Achievement Of Lampung University Faculty Of Medicine. JUKE Unila. Vol (4): 6-11

Slameto,. 2013. Belajar dan Faktor-Faktor Yang Mempengaruhi. Jakarta: Rineka Cipta. Hal 2-7, 54-63. 
Siska Anggreni Lubis, Mega Dwi Pertiwi, Saiful B : Hubungan Gaya Belajar Dengan Tingkat Prestasi Mahasiswa Fakultas Kedokteran Universitas Islam Sumatera Utara Angkatan Tahun 2013

Basri, H,. 2015. Paradigma Baru Sistem Pembelajaran. Bandung. Pustaka Setia. Hal 51$60,71-74$.

Ghufron, N,. Risnawita, R,. 2012. Gaya Belajar Kajian Teoretik. Yogyakarta: Pustaka Pelajar. Hal 4-13, 40-49.

Huda, M,. 2014. Model-Model Pengajaran dan Pembelajaran. Yogyakarta: Pustaka Pelajar. Hal 287-288.

Sudjana, N,. 2010. Penilaian Hasil Proses Belajar Mengajar. Bandung: Remaja Rosdakarya. Hal 22-34.

Ahmadi, A,. Supriyono, W,. 2013. Psikologi Belajar. Jakarta: Rineka Cipta. Hal 138-147.

Susila,. S. 2015. Metodologi Penelitian Cross Sectional. Klaten : BOSSSCRIPT.

Sundari,. 2009. Hubungan Tipe Belajar Dengan Prestasi Belajar Mahasiswa Program Ekstensi Fakultas Keperawatan Universitas Sumatera Utara. Skripsi. Medan : Fakultas Keperawatan Universitas Sumatera Utara.

Septiana, A,. 2012. Gambaran Gaya Belajar Dan Indeks Prestasi Mahasiswa Akademi Keperawatan sri Bunga Tanjung Dumai. Skripsi. Medan : Fakultas Keperawatan Universitas Sumatera Utara

Nurhidayah, R, E,. 2009. Learning Style Characteristic and Learning Outcomes Of Nursing Faculty Students Of University Of Sumatera Utara. Skripsi. Medan : Universitas Sumatera Utara.

Hardiansyah,. 2014. Pengaruh Gaya Belajar Terhadap Prestasi Akademik Mahasiswa Fakultas Kedokteran. Skripsi. Semarang : Fakultas Kedokteran Universitas Diponegoro. 